\title{
10. Water Planning and Dispossession
}

\author{
Jessica $\mathrm{K}$ Weir ${ }^{1}$
}

The policy failure of successive governments who over-allocated river water for agricultural consumption in the Murray-Darling Basin is now being addressed through the purchasing of 'environmental water' to boost river health. Already, 920 gigalitres of water has been purchased from farmers selling their consumptive-water entitlements to the Federal Government's Commonwealth Environmental Water Holder (CEWH). The Murray-Darling Basin Plan extends this work, proposing that an additional 2080 GL be purchased, to reach the target of 3000 GL. This planning is in line with the Water Act 2007 (Cwlth), which directs that the Murray-Darling Basin Authority (MDBA) develop a water-management regime that returns water extraction to environmentally sustainable levels.

The intention of both the Water Act and the Basin Plan is to respond to river degradation by bringing 'balance' to economic water use and the health of the river country, although $3000 \mathrm{GL}$ will restore river health only from poor to moderate (see Wahlquist, this volume). Such a deliberate response recognises that the prioritisation of water for agricultural production has neglected and impoverished our other river relationships. In this chapter, I explore the experiences of the traditional owners along the Murray River, particularly the elders who have witnessed dramatic changes to the river over their lifetimes. Continuing public and informal access to the inland rivers has provided important opportunities for traditional owners to enjoy those connections with their country that have persisted during the experience of colonisation. With the ecological degradation of the rivers, and the animals and plants they sustained, these enduring connections are being ruptured. Arguably, the traditional owners are experiencing this as a contemporary dispossession from their country.

\footnotetext{
1 This chapter is a revised and updated version of Weir, J. K. 2007, 'The traditional owner experience along the Murray River', in E. Potter, S. Mackenzie, A. Mackinnon and J. Mackay (eds), Fresh Water: New perspectives on water in Australia, Melbourne University Press, Carlton, Vic., pp. 44-58. The research for this chapter is supported by a research agreement arranged between myself and the Murray Lower Darling Rivers Indigenous Nations (MLDRIN). I particularly wish to acknowledge elders Richard Hunter and Agnes Rigney who are quoted in this article, and have since passed away. I thank MLDRIN for their support; however, the views expressed in this chapter are my own and do not represent the views of MLDRIN. My research was conducted as part of a PhD, funded by a Land \& Water Australia scholarship, and undertaken at the Centre for Resource and Environmental Studies (now the Fenner School of Environment and Society) at The Australian National University. I thank Deborah Rose for comments made on an earlier draft of this chapter.
} 


\section{Changing Water Flows}

River ecosystems in the Murray-Darling Basin are adapted to highly variable cycles of floods and droughts, and this variability has created a diversity of habitats in the river country (Young and Hillman 2001:92; Young et al. 2001:26$9)$. In the late nineteenth century, this river water was re-conceptualised as a resource for irrigated agricultural production. Large engineering projects began in the area during the 1920s. Since then, the rivers of the Murray-Darling Basin have been transformed by an extensive network of dams, weirs, locks, canals and pipes built to provide water to rural communities (Powell 1989). The dams now regulate the previously variable water flows by holding floodwaters back in large storages. Today, large water storages in the Basin have the capacity to store 35000 GL (1 GL equals the amount of water in 1000 Olympic-sized swimming pools). Annually, more than $10000 \mathrm{GL}$ are diverted from the rivers, and 96 per cent of this diverted water is used by farmers for irrigation (Crabb 1997:269). The large storages also provide water for rural towns and communities to survive in extended periods of drought.

With the reduced flow of water in the rivers, the networks of floodplains, wetlands, swamps and soaks have dried out. Or, where water is permanently stored, forests and country have been drowned. Combined with land-use changes around agriculture, there has been a dramatic decline in the quality of water. Sediment loads in the river are now 41 times their natural rate, outbreaks of blue-green algae poison the water, and increased salinity of the soil and water have all reduced the capacity of the rivers to be a productive source of life (Gehrke et al. 2003:3; Proust 2003). The consequences of all this for the birds, fish and other animals have been profound: their numbers have declined dramatically and certain species have experienced local extinction. Birds that used to nest when the floodwater came are not breeding successfully (Leslie 2001). Native fish populations are only 10 per cent of what they used to be (MDBMC 2003:6).

The change from the variable inland-river rhythm of floods and droughts is not just an overall decline in the size, length and frequency of floods; the timing of the flow of water has also changed. Along the Murray in the riverine plains, the river used to flood in autumn and winter. Now, water is released into the Murray in the spring and summer to flow downstream to irrigators for their agricultural crops - effectively reversing the seasonal pattern of the river's flow (Young and Hillman 2001:108). This has led to the unseasonal flooding of the Barmah-Millewa forest - a large wetland on the Murray River-destroying grasslands and trees (Chong and Ladson 2003:162-3, 165). 
By storing and diverting the river water, the dam builders have changed how the water flows across time and place, redistributing water over vast areas, entire communities and ecosystems (see also Mitchell 2002:21). Water management is not a discrete extraction of a resource from one location; rather, because of the capacity of water to move through landscapes and in seasonal rhythms, water management has consequences across basin ecosystems and through time. Because water is critical for all living things, there is now national concern about the scale of these consequences on peoples' lives, agricultural production, river health and species diversity. This concern includes losses in agricultural productivity from the increasing salt content of river water and agricultural land, in part also a result of land clearance for agriculture (Connell 2007, pp. 1718). The movement and flux of water have always been part of inland-river life, but modern engineering projects have brought accelerated change in the form of large water extractions, challenging the capacity of ecosystems to adapt and survive. The degradation of the river country, and the policy failure of overallocating river water, is now challenging the rural communities and livelihoods established next to the rivers.

The most dramatic changes to the rivers have occurred in the past 50 years, when the largest water storages were completed (Crabb 1997:29). This is within the lifetimes of the present generation of Aboriginal elders whose traditional country is in the Murray-Darling Basin. These changes are noted in the elders' dismay at the scale and speed of the ecological decline; as Mutti Mutti elder Mary Pappin (2004) has said: 'Such a short space of time! I can't take my grandchildren down to my favourite fishing spots and do what I used to do.'

\section{Indigenous Peoples' Experiences in the Murray-Darling Basin}

The fertility of the inland rivers has always drawn people to the region, in the past and today. The summer river flow of the Darling and the less seasonally variable flow of the Murray make locations adjacent to their banks attractive places to live. As hunting and gathering societies, traditional owners took advantage of seasonal fluctuations in resources (for example, the bogong moth feasts in the Snowy Mountains) (Flood 1976). In the arid and semi-arid lands, when the floods and rains came, the traditional owners were able to move camp from the rivers and out onto the plains (Allen 1980). In contrast, the Murray River Valley has also long been home to traditional owners living in river communities known for their high density and sedentary lifestyle (Webb 1984:168-70). 
In 1788 the British colony formally arrived in Sydney, and, in the early nineteenth century, the Darling, Murray, Lachlan, Macquarie and Murrumbidgee rivers provided the new settlers with the first routes of exploration inland to what is now known as the Murray-Darling Basin. For the colonisers, tributary junctions, fords and ferry crossings became settlement nodes, and the flat, fertile floodplains with easy access to the water provided the best conditions for agriculture (Smith 2001:213). Marcia Langton (2002:46) has described how colonisation and conflict in Australia focused on water, as the new settlers spread 'from water source to water source'. Aboriginal people demonstrated their objection to the land and water seizures by waging wars of resistance (for example, Gammage 1986; Read 1988).

Prior to colonisation, the Murray-Darling Basin was Aboriginal land, with rights and responsibilities for land and natural resources held between individuals and communal groups (Berndt et al. 1993:135-49). Since colonisation the Basin continues to be identified by the traditional owners as their country; however, they now have to argue for their rights and responsibilities to be recognised within the introduced European systems of law and governance. Of the small parcels of land that were allocated as reserves or missions for the traditional owners in south-eastern Australia, the majority was revoked in the twentieth century (for example, Goodall 1996). As their country was and is highly prized for agricultural production by the new settlers, the traditional owners have experienced the pressure of an early and concentrated settlement. This long and intensive experience of colonisation has also meant that much knowledge has been lost between the generations of Indigenous people during this experience of deprivation, stress, adaptation and survival (Tonkinson 1993:xxii).

The settlers brought new technologies and knowledge with them, and, as the settlers and their institutions became more established, Aboriginal people adapted and found meaning in the life and work of what is now rural Australia. The new rural industries that were instrumental in the appropriation of traditional country were also opportunities for independence for Aboriginal people within the colonial system. The desire to become farmers was a stated aspiration in Aboriginal peoples' petitions to government for land in the nineteenth and twentieth centuries, including the separate applications made by the Ngarrindjeri, Yorta Yorta, and Taungerung and Woiwurrung peoples (Barwick 1972:21, 49; Bell 1998:107). Wamba Wamba men became famous for being 'big-gun' shearers (Hercus 1992:15). With the spread of irrigated fields, seasonal work for large groups provided the opportunity for Aboriginal people to re-establish kinship networks (Taylor 1988:227-8).

Today, the Murray-Darling Basin is home to more than 70000 Indigenous people, which is 3.4 per cent of the total Basin population of two million people (Taylor and Biddle 2004). The disruption to traditional society since colonisation 
has created new identities among Aboriginal people, including 'historical people' and 'stolen generations'. Many Indigenous people continue, however, to primarily identify themselves and one another as traditional owners (Brennan et al. 2005:11). The traditional-owner identity is part of a long-held cultural, political and intellectual framework centred on the relationships people have with country, including the plants, animals and ecosystems of that country. There are at least 30 traditional-owner groups who have country within the Basin (MDBC n.d.:3).

These traditional identities have been transformed by the disruption and influence of colonialism, and today an important part of being a contemporary traditional owner involves building on and reviving cultural practices from earlier generations, such as teaching the local traditional languages and the performance of welcome ceremonies (Sutton 1995:47). Significantly, the traditional owners also continue to collect bush foods and medicines as a means for independence and as part of connecting with and affirming their identity (Behrendt and Thompson 2003:8; Clarke 2003). More generally, the traditional owners actively seek to increase their involvement in natural-resource and land-management policies and programs, such as pursuing joint-management arrangements over national park lands and establishing Indigenous advisory committees that engage with catchment management authorities.

\section{Ecological Loss and the Extinction of Experience}

Ethno-ecologist M. Kat Anderson has described the adverse impacts of the loss of ecosystems on the wellbeing of indigenous peoples in North America, revealing how interconnected ecological health is with the relationships indigenous people hold with their country (Anderson 1997). Indigenous peoples hold long-term associations with particular places and the species that live there, and, as a result, their identity, their ability to exercise their religion, their economic resources and their health are all intimately connected with the health of ecosystems. Anderson further argues that the perpetuation of indigenous knowledge about ecology requires access to that ecology. Due to these connections, the loss of ecosystems is also the loss of these dimensions of wellbeing for indigenous people. This argument about the connection between ecological health and indigenous peoples' wellbeing does not translate into a simple match between indigenous issues and environmental issues. The concerns indigenous people bring to environmental issues are much broader, and do not fit within the compartmentalism of environmental issues in Western knowledge frameworks (see further Braun 2002; Ingold 2000; Latour 2001; Strathern 1980; Weir 2009). 
This distinction has important implications for the degree of correspondence between environmental water allocations and water flows deemed necessary by indigenous people to maintain country (Weir 2009).

In the Murray-Darling Basin, the recent construction of large water-distribution projects is having an impact on the way of life of the traditional owners of the river country. My experience is from fieldwork with an alliance of traditional owners from along the Murray River in the southern part of the Murray-Darling Basin, which is also where irrigation activity is focused. ${ }^{2}$ Here, traditional owners are experiencing the degradation of river health within an intensively colonised part of Australia. The meandering inland rivers curve, loop and twist through landscapes that are now 'ordered' by agricultural production. Traditional country is fragmented, marked out by freehold and pastoral leaseholds, squares of irrigated fields, long lines of the roads and railways, and the life of the rural towns and communities. Here, the culture and lifestyle of traditional owners are part of modern intercultural Australian society (Merlan 2005).

As contemporary Indigenous peoples, the traditional owners I have worked with spoke to me about how they continue to collect bush foods and go fishing in the same places as their ancestors did. Such activities are not simply about recreation; they are about reaffirming relationships with country, connecting to intergenerational responsibilities, and practising traditional knowledge and skills. As Jason Behrendt and Peter Thompson have described, fishing is an opportunity for Aboriginal people to meditate on their relationship with country, without the need for colonial skills such as literacy, and in an activity in which Aboriginal knowledge is valued. Behrendt and Thompson (2003:8) write that going fishing is an important rest from colonisation: 'For a colonised people for whom political and geographical decolonisation are not realistic lifetime aspirations, opportunities to decolonise the mind are vital and life affirming.'

Traditional owners have spoken to me about how the enduring flow of the rivers connects them to their time scales and creation stories. Mary Pappin can imagine the Dreamtime when she is sitting by the river. The water, river, gum trees and wildlife make her feel that she is 'sitting right in it'. For Mary, this is a feeling of belonging: 'When I'm down by the river fishing or enjoying the bush, especially when I am resourcing it for bush foods, it just takes me straight back to the Dreamtime to continue on what my ancestors did, or nomads did, before the Europeans came' (Interview with author, 22 July 2004).

2 Here, the traditional owners have created an umbrella organisation called the Murray Lower Darling Rivers Indigenous Nations, which is formed by the Wiradjuri, Yorta Yorta, Taungurung, Wamba Wamba, Barapa Barapa, Mutti Mutti, Wadi Wadi, Latji Latji, Weragaia and Ngarrindjeri peoples (Weir 2009; Weir and Ross 2007). This alliance is a coordinated response to the devastation of the river country, so the traditional owners can better direct their engagements with government water management, law and policy in the Murray-Darling Basin. 
In terms of ecological loss, I focus on the impact of water regulation on fishing and the gathering of bush foods, medicines and materials, because the traditional owners repeatedly expressed this loss to me during my fieldwork. This focus reflects where the impact of water regulation is being particularly felt by the traditional owners, and how the activity and expertise of going fishing, or collecting certain bush tucker, have survived the experience of colonisation. Elsewhere, I have written at greater length about how the impacts of water regulation are being felt more comprehensively by the traditional owners, including issues of identity, economy, health and spiritual beliefs (Weir 2009).

In their expressions of ecological loss, the elders first reflected on times past when their lives were connected to the rivers through the essential act of drinking the water and eating the plants and animals that also lived by the river. In South Australia, Ngarrindjeri elders Matt Rigney, Richard Hunter and Agnes Rigney spoke to me about drinking water straight from the Murray River and its lakes when they were young. In those days, said Richard and Agnes, the water was so clear you could see the bottom of the river (Interviews with author, 23 July 2004 and 21 July 2004, respectively). Agnes Rigney described to me how she grew up in a 'semi-traditional' lifestyle next to the Murray River at the Swan Reach mission. Here, the Murray supplemented mission food with fresh water, fish, yabbies and waterbirds. Upstream in the Barmah Forest, Yorta Yorta elder Henry Atkinson told me how his father and mother's father were able to live off and make a living from fishing for native fish, mussels, Murray crayfish and turtles (Interview with author, 7 August 2004).

In comparison with such experiences, Richard Hunter spoke about all the fish that have 'disappeared in my short time' or are now found only in small numbers, including the iconic Murray cod. Matt Rigney spoke about the loss of native grasses, rushes and reeds that used to filter the waterways and provide clean water. Henry Atkinson spoke about the loss of the floods, and the drying out of the red-gum forests. In central New South Wales, Wiradjuri elder Tony Peachy spoke to me about the scarcity of native fish in the Macquarie River, and how he had not caught a Murray cod in five years (Interview with author, 29 October 2004). Further south along the Murrumbidgee, Mary Pappin worried about the loss of native fish in relation to the proliferation of the European carp, and the loss of medicine and bush-tucker plants that used to grow on the former floodplains, or in the little creeks that previously flooded intermittently.

Agnes Rigney linked the loss of native animal and plant life in the river country today to the loss of what she called 'cultural living'. My understanding, from listening to Agnes, is that cultural living reaffirms continuities with country through the practising and passing on of cultural knowledge and experience. Agnes spoke of this in relation to how different it was when she was a child: 
I remember as a kid growing up in Loxton how clear the river was, the water was, and my father actually making us spears from bamboo and we used to walk down to the river and we used to spear the fish. And it is just sad what's happened to it now. That was a part of cultural living, connected to the river, that we can't really practise anymore. (Interview with author, 21 July 2004)

Today, muddy waters and the absence of native fish preclude this practice. The loss and decline of river ecosystems has reduced the range of current and future possible activities for the traditional owners, including the practising of skills and the revival of lapsed traditions. For example, a part of cultural living celebrated among traditional owners of the inland rivers is the skill of basket weaving from the grasses and reeds that grow along the rivers or in the wetlands. Down in the Coorong behind the Murray mouth, the successful revival of basket weaving by Ngarrindjeri women is now threatened by the salt levels in the water, which means that the freshwater reeds are harder to find locally (Corowa 2006). Upstream in New South Wales near Deniliquin, Mutti Mutti elder Jeanette Crew talked to me about how she and local Wamba Wamba women - her friends and relatives - want to revive the art of making woven grass baskets. But the swamps where the best grasses for the baskets used to grow in the Werai Forest have been left dry by the over-consumption of river water, making it very hard to find grasses for this activity.

The impact of all these ecological losses on cultural living - which is crucial for a culture centred on intergenerational relationships with country - is alienating the next generation from experiencing their country as healthy and alive, and the opportunity of learning traditional knowledge and skills. Yorta Yorta woman Monica Morgan was a child in the 1960s. Her elders taught her the ecological cues that would tell her when swan eggs would be available up in the BarmahMillewa lakes. As Monica related: 'There was life...You'd sit there and they'd say, "Oh well the duckweed is coming down, that means the swan eggs are ready to go and be collected up in the lakes." So there were seasons happening' (Interview with author, 1 July 2004).

This is, however, a memory of the past. Today, the Murray floods out of season, and both the swans and the duckweed are rare. Monica is worried about the implications of this for Yorta Yorta children; she cannot teach them as she was taught, and the children are growing up without this knowledge and experience: 'So if I am seeing in just a short time - 20, 30 years - the disappearance of things that I took for granted, and were a real reflection of nature, and also governed my life cycles, then what is going to be left for our children?' (Interview with author, 1 July 2004). 
Robert Michael Pyle (1992) argues that the local loss of species is 'the extinction of experience'. When a species becomes extinct, all people lose direct, personal contact with that species. As time passes, the next generation does not have the opportunity to know the species, to interact with and identify with it. For Indigenous people, the local extinction of a species ruptures the transmission of intergenerational knowledge and skills because their knowledge is learnt and taught directly through experiences in country. Moreover, the ecological decline along the Murray is more than the local extinction of particular species. The over-extraction of water is affecting vast inland river ecosystems. By altering the distribution of water across time and place, the dam builders have altered the relationships between numerous traditional-owner groups and their country over thousands of kilometres. The twentieth-century changes to the water regime have broken connections passed down for a thousand generations, and instead offer the future diminishing and dying life.

The severe degradation of river ecosystems is a concern for all people living along the rivers. This chapter emphasises how the ecological loss and decline has particular consequences for the traditional owners of the river country. When the elders worry about not being able to go fishing or collecting bush tucker, they are concerned about the opportunity to continue being a traditional owner in a densely settled part of south-eastern Australia. Here, where the traditional owners do not have a large land base exclusively of their own, public access to the rivers, or mission lands, or informal agreements with private landholders have allowed for the continuance of cultural activities through the colonial experience. With the decline of the river ecosystems, these breaks in colonisation have been encapsulated and closed down. The alienation of the next generation from experiencing the life of the river country makes the elders feel that their cultural practice is threatened, and, I argue, compounds the experience of dispossession in south-eastern Australia.

The traditional owners are now part of intercultural rural society, and have benefited in part from the lifestyles and work opportunities provided by river regulation. Decisions about the scale and extent of water extraction have, however, been made without their consultation, or taking account of their interests, needs or rights - or the wider community more generally. Indeed, the foundation of water management, law and policy is premised on the exclusion of the pre-existing rights and interests of traditional owners. The language I have chosen to use - of dispossession - situates the ecological degradation of the river country within the colonial experience for the traditional owners. As Mary Pappin concludes: 'Somebody somewhere has made a decision on my behalf in taking that traditional resource away from me. From my way of looking at it, the Government is responsible for taking away the resource' (Pappin 2004). There is a growing body of research now addressing how to include 
the interests of Indigenous people in water planning, including the need to build Indigenous peoples and government capacity, and to address the failure to recognise Indigenous peoples' property rights in water (for example Jackson 2009, Jackson and Robinson 2009, Altman 2004).

Government decisions about water management-both the over-allocation of consumptive-water entitlements and the new policy of buying environmental water-have profound impacts on people because water is connected to so many important values. The impact of river degradation on Indigenous peoples' cultural life critically reveals this unique heritage that we are all losing when we lose our river ecologies.

The Murray-Darling Basin Plan's intention to return water to the river country, and restore river health, has the potential to address the traditional-owner experience of dispossession today and into the future. Traditional owners need to be part of that decision-making process, as the return of water to country is limited by vested interests in water consumption, and thus where and when small water amounts will be returned is determined by the priorities set by governments (see Jackson, this volume). Whilst the Basin Plan is a step forward to better recognise the primacy of river health, its modest goals to restore river health from poor to moderate reflect the continuing dominance of human consumptive needs in our water planning.

\section{References}

Allen, H. 1980, 'Aborigines of the western plains of New South Wales', in C. Haigh and W. Goldstein (eds), The Aborigines of New South Wales, New South Wales National Parks and Wildlife Service, Sydney, pp. 33-43.

Altman, J. 2004, 'Indigenous interests and water property rights', Dialogue, no. 23, pp. 29-33.

Anderson, M. K. 1997, 'California's endangered peoples and endangered ecosystems', American Indian Culture and Research Journal, vol. 21, p. 731.

Barwick, D. E. 1972, 'Coranderrk and Cumeroogunga: pioneers and policy', in T. S. Epstein and D. H. Penny (eds), Opportunity and Response: Case studies in economic development, Hurst and Co., London.

Behrendt, J. and Thompson, P. 2003, The recognition and protection of Aboriginal interests in NSW rivers, Occasional Paper 1008, Healthy Rivers Commission of New South Wales, Sydney. 
Bell, D. 1998, Ngarrindjeri Wurruwarrin: A world that is, was, and will be, Spinifex Press, Melbourne.

Berndt, R. M., Berndt, D. H. and Stanton, J. E. 1993, A World That Was: The Yaraldi of the Murray River and the lakes, South Australia, Miegunyah Press, Melbourne.

Braun, B. 2002, The Intemperate Rainforest: Nature, culture, and power on Canada's west coast, University of Minnesota Press, Minneapolis and London.

Brennan, S., Behrendt, L., Strelein, L. and Williams, G. 2005, Treaty, The Federation Press, Leichhardt, NSW.

Chong, J. and Ladson, A. R. 2003, 'Analysis and management of unseasonal flooding in the Barmah-Millewa Forest, Australia', River Research and Applications, vol. 19, no. 2, pp. 161-80.

Clarke, P. A. 2003, 'Twentieth-century Aboriginal harvesting practices in the rural landscape of the Lower Murray, South Australia', Records of the South Australian Museum, vol. 36, pp. 83-107.

Connell, D. 2007, Water politics in the Murray-Darling Basin, The Federation Press, Sydney.

Corowa, M. 2006, 'Murray, life + death', Message Stick, ABC TV, Sydney.

Crabb, P. 1997, Murray-Darling Basin Resources, Murray-Darling Basin Commission, Canberra.

Flood, J. 1976, 'Man and ecology in the highlands of southeastern Australia: a case study', in N. Peterson (ed.), Tribes and Boundaries in Australia, Social Anthropology Series No. 10, Australian Institute of Aboriginal Studies, Canberra.

Gammage, W. 1986, Narrandera Shire, Narrandera Shire Council, NSW.

Gehrke, P., Gawne, B. and Cullen, P. 2003, What is the Status of River Health in the Murray-Darling Basin?, CSIRO Land and Water.

Goodall, H. 1996, Invasion to Embassy: Land in Aboriginal politics in New South Wales, 1770-1972, Allen \& Unwin in association with Black Books, Sydney.

Hercus, L. A. 1992, Wemba Wemba Dictionary, Luise A. Hercus, Canberra.

Ingold, T. 2000, The Perception of the Environment: Essays in livelihood, dwelling and skill, Routledge, London. 
Jackson, S. 2009, National Indigenous Water Planning Forum: Background paper on Indigenous participation in water planning and access to water, A report by CSIRO Sustainable Ecosystems, to the National Water Commission.

Jackson, S and Robinson, C. 2009, 'Indigenous participation in water planning and management', in Northern Australia Land and Water Science Review, CSIRO.

Langton, M. 2002, 'Freshwater', in Background Briefing Papers: Indigenous rights to water, Lingiari Foundation, Broome, WA.

Latour, B. 2001, We Have Never Been Modern, Harvard University Press, Cambridge, Mass.

Leslie, D. J. 2001, 'Effects of river management on colonially-nesting waterbirds in the Barmah-Millewa Forest, South-eastern Australia', Regulated Rivers: Research \& Management, vol. 17, pp. 21-36.

Merlan, F. 2005, 'Explorations towards intercultural accounts of socio-cultural reproduction and change', Oceania, vol. 75, pp. 167-82.

Mitchell, T. 2002, Rule of Experts: Egypt, techno-politics, modernity, University of California Press, Berkeley and Los Angeles.

Murray-Darling Basin Commission (MDBC) n.d., Indigenous Basin Wide Gathering: Conference papers, presentations and outcomes, Murray-Darling Basin Commission, Canberra.

Murray-Darling Basin Ministerial Council (MDBMC) 2003, Native Fish Strategy for the Murray-Darling Basin 2003-2013, Murray-Darling Basin Commission, Canberra.

Pappin, M. 2004, Up the river forum, Message Sticks Festival, Sydney Opera House, May 2004.

Powell, J. M. 1989, Watering the Garden State: Water, land and community in Victoria, 1834-1988, Allen \& Unwin, Sydney.

Proust, K. 2003, 'Ignoring the signals: irrigation salinity in New South Wales Australia', Irrigation and Drainage, vol. 52, pp. 39-49.

Pyle, R. M. 1992, 'Intimate relations and the extinction of experience', Left Bank, vol. 2, pp. 61-9.

Read, P. 1988, A Hundred Years War: The Wiradjuri people and the state, The Australian National University Press, Canberra. 
Smith, D. I. 2001, Water in Australia: Resources and management, Oxford University Press, Melbourne.

Strathern, M. 1980, 'No nature, no culture: the Hagan case', in M. C. P. and M. Strathern (eds), Nature, Culture and Gender, Cambridge University Press, UK.

Sutton, P. 1995, Country: Aboriginal boundaries and land ownership in Australia, Aboriginal History, Canberra.

Taylor, P. (ed.) 1988, After 200 Years: Photographic essays of Aboriginal and Islander Australia today, Aboriginal Studies Press, Canberra.

Taylor, J. and Biddle, N. 2004, Indigenous people in the Murray-Darling Basin: a statistical profile, Discussion Paper No. 264, Centre for Aboriginal Economic Policy Research, Canberra.

Tonkinson, R. 1993, 'Introduction', in R. M. Berndt, D. H. Berndt and J. E. Stanton, A World That Was: The Yaraldi of the Murray River and the lakes, South Australia, Miegunyah Press, Melbourne.

Webb, S. 1984, 'Intensification, population and social change in southeastern Australia: the skeletal evidence', Aboriginal History, vol. 8, pp. 154-72.

Weir, J. 2009, Murray River Country: An ecological dialogue with traditional owners, Aboriginal Studies Press, Canberra.

Weir, J. and Ross, S. 2007, 'Murray Lower Darling rivers Indigenous nations', in F. Morphy and B. R. Smith (eds), The Effects of Native Title, ANU E Press, Canberra.

Young, W. J. and Hillman, T. J. 2001, 'A tale of two rivers', in W. J. Young (ed.), Rivers as Ecological Systems: The Murray-Darling Basin, Murray-Darling Basin Commission, Canberra.

Young, W. J., Schiller, C. B., Roberts, J. and Hillman, T. J. 2001, 'The rivers of the basin and how they work', in W. J. Young (ed.), Rivers as Ecological Systems: The Murray-Darling Basin, Murray-Darling Basin Commission, Canberra. 